\title{
REGULACIONES A UNA DEVOCIÓN ESTIGMATIZADA: CULTO A SAN LA MUERTE EN BUENOS AIRES
}

\author{
Juan Martin Lopez Fidanza ${ }^{1}$ \\ María Cecilia Galera ${ }^{2}$
}

\begin{abstract}
Resumen: En este trabajo abordamos el culto a San la Muerte, santo de consagración popular oriundo de las provincias del litoral argentino con influencia de la cultura guaraní, y de gran expansión en la actualidad. Esta devoción se hace presente en el espacio público y acrecienta su visibilidad en un marco de una menor restricción estatal sobre los cultos; constatado en la existencia de múltiples santuarios y altares a lo largo del país, su difusión en sitios Web, santerías y en los medios de comunicación. Aun así, esta devoción continúa siendo estigmatizada y supone costos sociales para aquellos que le rinden culto. En este contexto, nos interesa abordar las diversas regulaciones estatales y sociales sobre este culto. En particular, haremos hincapié en la presentación que realizan los medios de comunicación (en el período 2008-2011) sobre esta devoción, la cual consideramos refuerza una imagen negativa y vinculada con el crimen en el imaginario colectivo. Por último, abordaremos las estrategias de legitimación que despliegan los encargados de santuarios a San La Muerte en Buenos Aires en tanto referentes de esta devoción popular.
\end{abstract}

Palabras clave: Religiosidad Popular; Regulaciones; Medios de Comunicación; Estrategias de Legitimación.

Abstract: In this paper, we are going to address the cult of the popular saint San La Muerte, which was emerged in the argentine provinces with Guaranís culture influence and of great expansion at present. This devotion is expanding throughout the country and increases its visibility in a context of greater religious market deregulation; this can be perceived in his presence in multiple altars erected in public places and shrines, websites or the mass media. Even so, the devotion to San La Muerte is still socially stigmatized and involves social costs for those who worship him. Therefore, we would address the many social and state regulations

1 Pontificia Universidad Católica Argentina (UCA). Buenos Aires, Argentina. Contacto: juanfidanza@gmail.com.

2 Consejo Nacional de Investigaciones Científicas y Técnicas (CONICET) - Universidad de Buenos Aires. Buenos Aires, Argentina. Contacto: mceciliagalera@gmail.com.

Debates do NER, Porto Alegre, ano I5, N. 25, P. I7i-I96, JAn./Jun. 2014 
to this cult and the legitimation strategies deployed by this saint sanctuary's owners in Buenos Aires. We will focus on the presentation made by the media (in the period 2008-2011) on this devotion, which we believe reinforces a negative image associated with crime in the collective imagination, limiting the freedom of expression of the devotees and the spread of devotion.

Keywords: Popular Religiosity; Regulations; Mass Media; Strategies of Legitimization.

\section{INTRODUCCIÓN}

Dentro de la producción académica sobre el campo religioso argentino, diversos autores lo analizan desde una perspectiva que postula la existencia de un 'monopolio' católico en donde la Iglesia se impondría como garante privilegiado de la autenticidad de las creencias, aunque esto no suponga necesariamente una regulación efectiva sobre las prácticas. Este status sufriría una ruptura en las últimas décadas, dando lugar a una fragmentación y pluralización de grupos religiosos (Mallimaci, 2013; Mallimaci; Giménez Beliveau, 2007; Mallimaci, 2001; Gimenez Beliveau; Esquivel, 1996). Esta línea de análisis ha sido cuestionada por Frigerio (2007), quien señala que detrás de la misma subyace la asunción acrítica del modelo bergeriano de 'dosel sagrado' así como la postulación de un hipotético pasado en el cual existiría de hecho una situación monopólica, la cual no ha podido ser corroborada por investigaciones históricas. Como alternativa, se postula la utilidad de pensar el contexto argentino desde la perspectiva de las economías religiosas (Frigerio, 2007; Frigerio; Wynarczyk, 2008), desde la cual se estudia el grado de regulación ejercido sobre organizaciones e individuos en lo referente a la práctica de su libertad religiosa. Este modelo fue desarrollado para explicar las variaciones de la actividad religiosa en el mercado, particularmente norteamericano. Una de sus principales tesis es la siguiente: si una economía religiosa no está regulada y es competitiva, los niveles generales de compromiso religioso serán altos (Stark; Finke, 2000). Esta teoría afirma que la regulación sobre la religión restringe la oferta religiosa modificando los incentivos y oportunidades para los 'productores' (líderes 
y organizaciones religiosas). Las religiones con regulaciones restrictivas enfrentan mayores costos de entrada y de operación, por lo que no pueden competir en igualdad de condiciones con las religiones favorecidas, o al menos toleradas, por el Estado (Stark; Finke, 2003).

Dentro de esta perspectiva teórica, resaltamos el aporte de Grim y Finke (2006), quienes presentan dos grandes tipos de regulaciones que impactan en las formas de concebir y vivir la religión. Por un lado, la regulación gubernamental que consiste en las restricciones sobre la práctica, profesión o elección de una religión ejercidas por leyes, políticas oficiales o acciones administrativas del Estado. Estas regulaciones son las más directas y visibles para un observador externo, siendo comúnmente trabajadas desde distintas perspectivas teóricas, especialmente aquellos estudios que investigan los vínculos Estado-Iglesia. El favoritismo religioso estatal ${ }^{\beta}$ es definido como aquellos subsidios, apoyos, privilegios o sanciones favorables provistas por el Estado a una religión determinada o a un pequeño grupo de éstas. Puede deberse a una modalidad centralizada, planificada e incluso legislada; o bien ser resultado de la decisión personal de funcionarios estatales. En este registro deben entenderse también los subsidios a organizaciones religiosas que no se destinan al culto sino a los servicios de educación y acción social que ofrecen, labores que a la larga resultan difícilmente escindibles del carácter religioso de dicha institución.

Estas regulaciones sobre lo religioso, sean restrictivas o positivas, atraviesan los tres poderes del Estado, en sus diferentes niveles (nacional, provincial y municipal). El marco regulatorio en sí es definido por el poder legislativo quien dicta las leyes pertinentes, basándose en lo estipulado por la Carta Magna de cada país. En el caso argentino la Constitución, a pesar de que no adopta una religión 'oficial', evidencia un claro favoritismo en beneficio de la Iglesia Católica. Sin embargo, las regulaciones no se restringen a la formalidad de la ley (Constituciones, Leyes nacionales o provinciales, legislaciones locales) sino que también contemplan sanciones o perjuicios

3 Estos dos tipos de regulación deben distinguirse pese a tener un mismo actor, debido a que tienen efectos distintos, en cuanto a su carácter restrictivo o positivo. Sin embargo, debe señalarse que ambos mecanismos suelen operar en conjunto.

Debates do NER, Porto Alegre, ANo I5, N. 25, P. I7I-I96, Jan./Jun. 2014 
originados en acciones administrativas, una modalidad de regulación menos evidente y, por ende, difícil de indagar.

Por otro lado, entre las regulaciones estatales podemos distinguir aquellas establecidas formalmente (institucionalizadas) y los ordenamientos informales que transcurren entre lobbies, presiones y estrategias políticas que se gestan en estrecho vínculo con el contexto socio-político del momento. En este nivel también operan lógicas culturales o personales de quienes detentan cargos de decisión. La coyuntura atraviesa las diversas instancias del Estado, ya sea en la decisión burocrática de algunos funcionarios (favoreciendo $\mathrm{u}$ obstruyendo), en los procesos judiciales, en la inclusión o exclusión de algunos artículos en leyes, etc.

Existen otros organismos pertenecientes a la esfera pública que impactan en el desenvolvimiento de la vida cotidiana de los grupos religiosos. En primer término, destacamos aquellos poderes ligados al monopolio legítimo de la violencia, como es la policía. A pesar de que la normativa actual que regula el campo religioso argentino no conlleva un control represivo, a través de los medios de comunicación se tiene conocimiento de diversos hechos en que esta institución ha actuado extrapolando valoraciones personales en su accionar como fuerzas de seguridad.

Por último, Grim y Finke (2006) señalan un tipo de regulación que excede el marco estatal: las regulaciones sociales. Estas son restricciones sobre la práctica, profesión o elección de una religión ejercidas por otros grupos religiosos, y diversos sectores de la sociedad. Puede tratarse de acciones directas de representantes religiosos, fieles que ocupan puestos relevantes en alguna organización secular y pueden incidir en la regulación de la cultura, repudios vecinales, información que circula en los medios de comunicación, etc. Hay un amplio espectro de actores religiosos y agentes seculares que operan en la esfera pública atribuyéndose cierto conocimiento 'experto' y buscando influir de modo más o menos directo sobre el desenvolvimiento de la vida religiosa. Entre ellos podemos incluir: periodistas, profesionales de la salud, académicos, activistas anti-sectas, editores de libros de temática religiosa, policías, psicólogos, entre otros. Este tipo de regulación es mucho más difícil de percibir y medir por su pluriformidad y por las formas sutiles 
que puede adoptar: desde asignaciones de un estatus 'desviado' a persecuciones abiertas por grupos organizados (Frigerio, 2012).

En el caso argentino, podemos observar el impacto de las regulaciones sociales sobre la diversidad religiosa, retomando el caso de los grupos evangélicos y umbandistas en los '90. Pese a que la legislación referida a la libertad de culto (considerada deficiente por muchos especialistas) se ha mantenido casi inalterada en las últimas dos décadas, estos grupos religiosos debieron redoblar sus esfuerzos en el espacio público en pos de mejorar su imagen en los medios de comunicación, donde eran fuertemente estigmatizados (Frigerio; Wynarczyk, 2008).

La importancia de indagar en todas estas regulaciones radica en abrir el juego a las acciones gubernamentales - marcos legales, restricciones administrativas o judiciales, favoritismos políticos - e interacciones sociales en torno a los diversos cultos, dando cuenta de cambios y resistencias en el desarrollo de los mismos (Frigerio; Wynarczyk, 2008). Principalmente habilita la observación del desenvolvimiento de grupos minoritarios en la vida cotidiana y las regulaciones sociales (como el impacto de los medios de comunicación, persecuciones, estigmatizaciones, etc.) que operan sobre ellos en un contexto de mayor diversidad y visibilidad religiosa en el espacio público. Consideramos que la práctica o elección de una religión se podría ver modificada por restricciones derivadas de una regulación gubernamental (normas legales y decisiones administrativas dictaminadas sobre los diversos grupos), y por otro lado, limitaciones y controles sociales y culturales, dando cuenta de una regulación religiosa extra-legal.

En este artículo analizaremos las regulaciones a una devoción que, sin ser proscripta, sufre de claros costos adicionales para quienes la practican: el culto a San la Muerte. Se trata de una devoción popular, originaria del litoral argentino con influencia de la cultura guaraní, que actualmente se ha expandido por todo el territorio argentino y ha acrecentado su visibilidad en un marco de mayor desregulación del mercado religioso. En este contexto, nos interesa abordar las diversas regulaciones estatales y sociales sobre este culto. En particular haremos hincapié en la presentación que realizan los medios de comunicación (en el período 2008-2011) sobre esta devoción, la

Debates do NER, Porto Alegre, Ano I5, N. 25, P. I7i-I96, JAn./Jun. 20 I4 
cual consideramos refuerza una imagen negativa y vinculada con el crimen en el imaginario colectivo. Por último, abordaremos las estrategias de legitimación que despliegan los encargados de santuarios a San La Muerte en Buenos Aires en tanto referentes de esta devoción popular. ${ }^{4}$

\section{EL CULTO A SAN LA MUERTE}

San La Muerte es un santo consagrado popularmente, no reconocido por ninguna institución religiosa tradicional ni ente gubernamental. Su culto proviene del nordeste argentino y Paraguay, regiones con influencia de la cultura guaraní. Desde mediados del siglo pasado se ha ido propagando al resto de Argentina a través de migraciones internas ${ }^{5}$, y posteriormente por la visibilización creciente de esta devoción en los medios de comunicación e Internet, en un contexto que favorece - en parte - su presencia pública.

Su origen surgiría de la hibridación de creencias guaraníes con elementos traídos por la evangelización católica. La representación iconográfica que suele asociarse con San La Muerte entronca con las imágenes medievales europeas de la muerte (Duarte García, 2003). Una figura esquelética erguida, generalmente cubierta con una túnica y provista de una guadaña; la cual a veces aparece sentada en un trono ${ }^{6}$.

4 Este artículo es fruto de nuestro trabajo de campo (del 2010 a 2013) en tres santuarios de San La Muerte ubicados en ciudad de Buenos Aires y conurbano bonaerense, en los cuales realizamos observación participante y entrevistas. Adicionalmente, hicimos relevamientos online, análisis de documentos referidos a las regulaciones gubernamentales y análisis de contenido para el estudio de los medios de prensa escrita.

5 A partir del gran afluente migratorio proveniente de la región litoraleña del país, la devoción a San La Muerte se asentó en el conurbano bonaerense, que es hoy una de sus áreas de mayor desarrollo: prácticamente la mitad de los santuarios se ubican en esta zona.

6 Una segunda vertiente iconográfica presenta una estética no europea de la muerte: un esqueleto sentado o acuclillado, que es relacionado tanto con las representaciones cristianas del 'Señor de la Paciencia' (las clásicas representaciones del Ecce homo) como, en menor medida, a la posición que adoptaba el payé (hechicero) guaraní. Esta iconografía la encontramos regularmente abundante en los registros fotográficos de los escritos

Debates do NER, Porto Alegre, Ano I5, N. 25, P. I7I-I96, JAN./Jun. 2014 
Hay diversas formas de acceder al culto: algunos lo hacen por su afiliación familiar y comunitaria (sobre todo aquellos que son oriundos de la zona del litoral y norte del país), otros se acercan al santo por su popularidad en aumento como dispensador de grandes milagros y favores, asociado también a la expansión de la devoción al santo popular 'Gauchito Gil'. El sujeto empieza a construir un vínculo personal y de intercambio con el Santo a partir de un pedido de intervención milagrosa en problemas concretos de su realidad cotidiana, principalmente en una situación crítica propia o de algún familiar (vinculada a la salud, lo económico-laboral, situación amorosa, etc.) y que requiere inmediata resolución. También recurren a sus poderes aquellos devotos interesados en procurar un mal, dañar a otras personas, y destruir enemigos. El trabajo con fuerzas oscuras suele traer aparejada una serie de advertencias en el imaginario religioso, en donde el devoto - y en algunos casos quien le realiza el trabajo -, debe hacerse responsable de las contrapartidas que puede suponer su pedido y los castigos severos de los que puede hacerse acreedor en caso de no cumplir con lo prometido. Para algunos devotos el santo es 'justo y vengativo', por lo que no conviene invocarlo en vano ni incumplir la obligación prometida a cambio de su protección.

Como en toda devoción popular, los devotos tienen una amplia libertad de apropiación y forma de vincularse con el santo. Igualmente su figura nuclea y congrega a una gran cantidad de devotos que establecen ciertas convenciones en los modos de brindarle devoción a partir de la socialización de experiencias y prácticas religiosas. En esta propagación tienen un rol importante los santuarios, las redes sociales en Internet, las páginas Web dedicadas al santo, y los libros de difusión en Santerías. Estas fuentes diversas de información instruyen al devoto (sin importar que los textos se reorganicen según otras corrientes religiosas como umbanda, espiritismo y/o New Age) y generan cierta coherencia en la creencia y conformación de códigos compartidos, frente a la ausencia de una doctrina unificada (López Fidanza; Galera, 2011). Frente al santo se prenden velas y disponen ofrendas, mediaciones que fomentan el intercambio con lo sagrado y sostienen la

folklóricos de mediados del siglo pasado (Miranda Borelli, 1963; Cerruti, 1965; Noya, 1968). Actualmente es escasa su presencia en los santuarios.

Debates do NER, Porto Alegre, ano i5, N. 25, P. I7i-I96, JAn./Jun. 20 I4 
cadena de pedidos, favores concedidos y agradecimientos. Estos símbolos cumplen funciones cotidianas en tanto protectores y defensores frente a las 'fuerzas malignas'. El disponer de un altar -ya sea hogareño como público-, en pos de procurar una experiencia próxima del santo protector, supone un conjunto de prácticas devocionales en su confección. Hay una disposición determinada de un conjunto de objetos significativos para el culto, en un espacio propicio para la contemplación religiosa, un mantenimiento cotidiano y la renovación constante de las ofrendas. Estas son variadas: desde cigarrillos y alimentos (golosinas) hasta bebidas alcohólicas (generalmente de alta graduación: whisky, caña, licores, aunque también hemos observado vino tinto), flores (principalmente claveles rojos), objetos de oro y velas de diverso color según la intención del pedido.

\section{LAS REGULACIONES GUBERNAMENTALES A LA DEVOCIÓN}

En la Argentina no existen actualmente regulaciones que proscriban actividades o grupos religiosos, pero las condiciones para el desempeño de las diversas organizaciones no son homogéneas. Las religiones minoritarias (como por ejemplo, la Umbanda) han recorrido un largo camino en pos de contrarrestar su estigmatización social y adquirir mayor presencia pública. Para el caso argentino, es útil la jerarquización de religiones de acuerdo al trato recibido por el Estado, que propone Richardson (2006). Según el autor, existe una religión con marcado favoritismo (el catolicismo), muchas organizaciones religiosas 'aceptables' con beneficios limitados, e instituciones religiosas que carecen de todo beneficio por parte del Estado. El último escalafón propuesto por este autor - grupos religiosos prohibidos, perseguidos y castigados - no tiene lugar en la Argentina actual desde una perspectiva legal.

Los artículos 14 y 20 de la Constitución argentina, desde su primera redacción, consagran la libertad de culto. Siguiendo el mandato del artículo 2 de la Constitución, existe un 'favoritismo estatal' hacia la Iglesia Católica (Frigerio; Wynarczyk, 2008), siendo la única institución religiosa que recibe 
privilegios y subsidios ${ }^{7}$. En esta línea, de acuerdo al Código Civil vigente ${ }^{8}$ en su artículo 33, esta institución es la única entidad no estatal reconocida como persona jurídica de carácter público. Cualquier otro grupo religioso debe constituirse como una asociación civil ${ }^{9}$, tramitando una personería jurídica de carácter privado.

La única legislación nacional vigente en materia religiosa es la Ley $\mathrm{N}^{\circ}$ 21.745 (10 de febrero de 1978) que crea el 'Registro Nacional de Cultos' radicado en el actual Ministerio de Relaciones Exteriores, Comercio Internacional y Culto ${ }^{10}$. La Dirección a cargo de dicho Registro oficia de nexo entre el Estado y las diversas confesiones (a excepción de la Iglesia Católica), centralizando las gestiones de las organizaciones religiosas inscriptas ante las autoridades públicas. Esta ley, gestada durante la presidencia de María Estela Martínez, fue sancionada por el último gobierno de facto, con cláusulas claramente policíacas ${ }^{11}$. Dicho cariz fue matizado con el tiempo ${ }^{12}$, sin por ello dejar de haber trabas en la gestión del registro (Frigerio; Wynarczyk,

7 Concretamente, reciben este subsidio permanente la jerarquía católica (obispos), parroquias de frontera y los recursos humanos en formación (seminarios). Existen otros subsidios que no son otorgados a la Iglesia Católica en cuanto sostenimiento del culto, sino en relación al desempeño de una función (escuelas, asistencia social, etc.)

8 Actualmente se encuentra en discusión en el Congreso Nacional un proyecto de reforma y unificación de los Códigos Civil y Comercial que mantiene la situación actual.

9 La personería jurídica no otorga un reconocimiento religioso, este se obtiene a través del Registro Nacional de Culto. Según la normativa vigente esta personería sólo se podrá otorgar a posteriori de dicho reconocimiento, el cual a su vez exige como requisito tener un estatuto de constitución; planteando una recursividad contradictoria en la ley.

${ }^{10}$ Este Registro tuvo su antecedente en el 'Fichero de Cultos' creado en el primer gobierno peronista (Bianchi, 2003).

$11 \mathrm{Su}$ artículo 3ro permite denegar la inscripción solicitada o cancelar la misma si los principios constituyentes de la asociación o sus actividades "resultar en lesivas al orden público, la seguridad nacional, la moral y las buenas costumbres”. Dicha formulación permite un alto grado de discrecionalidad en su aplicación. El artículo $4^{\circ}$ habilita para estos casos "la prohibición de actuar en el territorio nacional".

12 [...] dicha obligación [de inscribirse] debe interpretarse razonablemente a fin de armonizarla con los derechos de la libertad religiosa reconocidos a todos los habitantes,

Debates do NER, Porto Alegre, ano i5, N. 25, P. I7i-I96, JAn./Jun. 2014 
2008; Catoggio, 2008). La obligatoriedad de la inscripción no se interpreta con el peso que marca el texto de la norma, existiendo múltiples grupos religiosos que desarrollan sus actividades al margen del Registro de Cultos. Sin embargo, la inscripción supone ciertas ventajas como la habilitación para pedir exenciones impositivas, obtener la personería jurídica y poder gestionar subsidios o autorizaciones de los organismos competentes para desarrollar distintas actividades abiertas a la comunidad.

La actual gestión, llevada adelante por una funcionaria no católica por primera vez, según su testimonio -, se reconoce más inclusiva que los anteriores responsables del Registro ${ }^{13}$. Sin embargo, no por ello deja de haber un costo elevado para las organizaciones religiosas, como las vinculadas con San La Muerte y otras devociones populares. El trámite de inscripción no requiere la intervención ni la asesoría de un letrado, pero la confección de todos los documentos a presentar supone un saber que no necesariamente poseen los agentes religiosos de los santuarios ni muchos de sus fieles. Las deficiencias en esta instancia formal suelen perjudicar el proceso de inscripción siendo en algunos casos el motivo de su estancamiento.

En el caso particular de la devoción a San la Muerte, se realizaron dos solicitudes de inscripción por parte de sendos santuarios ${ }^{14}$ que fueron rechazadas. Según nos informó la directora del Registro de Cultos, se alegó que no contaban con los requerimientos formales para su inscripción aunque si esta hubiera cumplido con todas las formalidades, difícilmente habría sido aprobada debido al "impacto mediático que puede implicar que el Estado reconozca un culto de estas características [...] hay un nivel de confrontación que se quiere evitar”. Según su punto de vista, hay dos dificultades

personal y colectivamente, por la Constitución Nacional y los tratados internacionales con jerarquía constitucional” (Resolución Secretaría de Culto N³.307/00).

${ }^{13}$ En 2000 las instituciones inscriptas eran 2300; en 2006 alcanzaban las 3600 y en 2012 orillan las 4700 .

${ }^{14}$ Uno de los santuarios visitados durante el trabajo de campo sostiene estar inscripto como culto, publicitándolo en su sitio web e identificándose con el No 6855. Sin embargo,dicho número no corresponde a un Certificado de Inscripción del Registro, según corroboramos en dicho organismo.

Debates do NER, Porto Alegre, Ano I5, N. 25, P. I7I-I96, JAN./Jun. 20 I4 
en este tipo de inscripciones: a) la carencia de una definición por parte del Estado respecto de qué es 'religión' y qué no es, y b) los valores culturales de nuestra sociedad, que aún no percibe la diversidad religiosa como un bien. En palabras de la Directora: "Imaginémonos si incorporamos [...] el esqueleto, o un culto específico a la posibilidad de la muerte, la divinización de la muerte. Acá está el problema: una cuestión social”.

Las organizaciones religiosas no registradas, como por ejemplo los santuarios dedicados a santos populares, no son consideradas ilegales $-\mathrm{y}$ por ello no debieran ser criminalizados por la policía. Las consecuencias de la no inscripción, recaen sobre la legitimidad social del culto y en la imposibilidad de tener un vínculo formal con el Estado, aunque se dan algunas excepciones a nivel municipal. De hecho, en varios casos hemos recibido testimonios de la intervención de la municipalidad en la organización de los festejos para el día del santo (poner escenario, permiso para el corte de calles) sin haber mediado la Dirección del Registro Nacional de Cultos. Otro ejemplo en la provincia de Corrientes, es la incorporación de la devoción a las recomendaciones turísticas de la zona, llevándonos a pensar en una incipiente "patrimonialización del culto". ${ }^{15}$ Un caso paradigmático se dio en la ciudad de Godoy Cruz en donde para evitar que se erigiera una ermita a este santo, se sancionó una norma que requiere la aprobación de al menos el $50 \%$ de los residentes próximos, para la instalación de una imagen religiosa en el espacio público.

\section{LAS REGULACIONES SOCIALES SOBRE LA DEVOCIÓN A SAN LA MUERTE}

En la actualidad, consideramos de relevancia - y poco estudiadas - las múltiples regulaciones sociales en la vida cotidiana que aumentan el costo social de profesar este tipo de creencias. La devoción a San la Muerte recupera diversas tradiciones religiosas y culturales, pudiéndosela ubicar en los

15 Esta 'patrimonialización' no llega al nivel excepcional de la Difunta Correa en Vallecito San Juan - o de Ceferino Namuncurá en Chimpay - Río Negro -, donde se reestructuró la fisonomía de la ciudad orientándose a esta devoción y sus diversas manifestaciones de fe.

Debates do NER, Porto Alegre, ano i5, N. 25, P. I7i-I96, JAn./Jun. 2014 
márgenes difusos del catolicismo popular aunque sin reconocimiento oficial por parte de la Iglesia Católica e incluso siendo impugnada por ella. Este rechazo no se traduce en un repudio social directo, dado que las directivas eclesiales no ejercen una regulación efectiva y cotidiana en las prácticas y juicios de la población. Sin embargo, estos discursos influyen en la construcción de imaginarios que se nutren de símbolos religiosos (Mallimaci; Giménez Beliveau, 2007) y permean en las matrices culturales de la sociedad. La valoración de los fenómenos religiosos, aún por fieles de otras religiones o por no creyentes, está impregnada del 'patrón de religiosidad del catolicismo'. Este puede ser entonces considerado como un marco interpretativo, un esquema, un modelo de comprensión de los valores y prácticas religiosas, un hábitus "que moldea la experiencia religiosa aún de quienes ya no se consideran católicos sino umbandistas, espiritistas o pentecostales" (Frigerio, 2007). Dicha influencia cobra particular importancia cuando vehiculiza acciones gubernamentales. La Directora del Registro de Cultos daba cuenta del reconocimiento de este condicionante cultural del catolicismo respecto de lo religioso: "Esa virgen o el crucifijo de los jueces es a los afectos, al inconsciente colectivo, como el obelisco, como las palomas y la plaza de mayo. Es parte 'del ser nacional'. Es todo una cultura que hay'. (Entrevista a Directora del Registro Nacional de Cultos, 2012).

Esta impugnación católico-céntrica se cruza y refuerza con otra que identifica esta devoción con el mundo del delito. El culto a San La Muerte enfrenta esta complejidad adicional: la apropiación (no necesariamente religiosa) de esta figura como signo de transgresión. Por la creencia en su capacidad de resguardar contra la muerte a quien lo lleva tatuado o "incorporado" (incrustación bajo la piel de imágenes/payé), San la Muerte es un santo comúnmente apropiado por aquellos sectores sociales que conviven con situaciones de violencia, sobre todo jóvenes en conflicto con la ley y privados de la libertad. Míguez y Gonzales (2002) proponen que esta vinculación con el delito y la transgresión no estaba tan arraigada en los orígenes de la devoción, sino que se va configurando a lo largo del tiempo.

Ya sea por el atractivo de su estética amenazante (vinculada con la muerte y la violencia) como por el resguardo que garantiza su invocación divina, una práctica regular entre sus seguidores es la impronta de tatuajes

Debates do NER, Porto Alegre, ANo I5, N. 25, P. I7I-I96, JAN./Jun. 20 I4 
en el cuerpo. Estas 'marcas' en el contexto actual conllevan riesgos de apresamientos, hostigamientos policiales, estigmatizaciones sociales, que refuerzan la identidad del joven delincuente (Míguez, 2002). Carozzi y Míguez (2005) complejizan este fenómeno al proponer que el uso de tatuajes por parte de jóvenes de sectores suburbanos empobrecidos puede responder a una apropiación estética de la imagen, y no necesariamente supone una práctica devocional ni conocimientos sobre la tradición de este culto. Esta realidad es generalizada por los medios de comunicación para el resto de los devotos, atribuyéndoles una carga estigmatizante.

\section{LA ESTIGMATIZACIÓN EN LOS MEDIOS}

La figura de San La muerte ha estado presente en los medios de comunicación a lo largo de las últimas dos décadas. Tenemos testimonios de su aparición en distintos diarios, siempre de modo esporádico y como un fenómeno 'peculiar y atemorizante'. Sin embargo, desde 2010, puede percibirse en los medios gráficos de mayor tirada una frecuencia inusual menciones en diversas noticias. Sorprende no solo esta asiduidad, sino la conformación de una imagen ligada al delito como referencia obligada. Para poder comprobar empíricamente esta percepción, procedimos a analizar la imagen construida en algunos de los diarios de mayor presencia a partir de las menciones de esta devoción. ${ }^{16}$

El primer elemento a destacar es el crecimiento de la cantidad de notas con referencias a esta devoción, en donde las menciones entre 2008-2009

${ }^{16}$ De entre los medios de prensa escrita de difusión diaria de alta tirada, seleccionamos siete diarios (2 de alcance nacional, 5 de alcance regional). Como criterio de muestreo determinamos elegir los diarios que superen una tirada de 35.000 ejemplares semanales, de acuerdo a los datos disponibles en www.ivc.org.ar que permitiesen acceder en sus sitios web a noticias desde 2008. De este modo, nuestra muestra quedó conformada por las noticias que mencionaban a San La Muerte en los siguientes diarios: La Nación, Clarín, Los Andes (Mendoza), La Capital (Santa Fe), La Gaceta (Tucumán), El Día (La Plata), El Norte (Resistencia). El período elegido es 2008- 2011, en el cual se registra un total de 112 artículos periodísticos, de diversa índole, que mencionan a este santo: 2008, 12 menciones; 2009, 6 menciones; 2010, 50 menciones; 2011, 43 menciones.

Debates do NER, Porto Alegre, ano i5, N. 25, P. I7i-I96, JAn./Jun. 20 I4 
(19) son quintuplicadas por las de 2010-2011 (93). Particularmente elevado es la frecuencia correspondiente a 2010. Este aumento puede ser percibido en todos los medios. ¿Cómo explicarlo? Si uno agrupa las noticias según los hechos que cubren, nos encontramos que desde julio de 2010 se sucedieron una serie mensual de hechos delictivos que, de un modo u otro, hacían referencia a San La Muerte. ${ }^{17}$

Entre todos estos casos, con 29 menciones sobresale el de 'Marcelito', representando el 25,9\% del total de noticias referidas a San La Muerte en este período. El mismo fue cubierto por varios días y con gran repercusión luego de su detención. La temática de 'pacto' según el cual este joven ofrecía una vida humana por semana a cambio del favor del santo (dinero, drogas, protección) generó gran revuelo. En los diarios se sucedieron notas que pretendían ilustrar sobre esta devoción, nutriéndose de artículos periodísticos de años anteriores y, principalmente, extrayendo información de las páginas web dedicadas a este santo. ${ }^{18}$ La presencia de este culto en ámbitos

17 Presentamos los casos sumariamente. Julio: un parapsicólogo que decía tener poderes delegados por San La Muerte. Es asesinado por su hijo, que lo acusa de 'brujo'. Agosto: un joven de un barrio carenciado es acusado por 7 homicidios que habrían sido realizados, según testimonios, por un 'pacto' con San La Muerte. Septiembre: 3 individuos integraban una 'banda' que asaltaba comercios en la ciudad de Rosario. Se movilizaban en 2 autos con una gran calcomania de San La Muerte cubriendo el capot. En el allanamiento encuentran un altar al santo en la casa. Noviembre: una persona es encontrada muerta en su auto con indicios de haber sido asesinada por un 'ajuste de cuentas'. Los medios destacan que tenía entre otros tatuajes, uno de San La Muerte en la pierna. Diciembre: un miembro de una banda que atacó un camión de transporte de caudales y estaba prófugo, es hallado y escapa en una camioneta robada, llamando la atención de los medios que lo hiciese con una estatua de San la Muerte en el asiento de atrás. Estos cinco casos, que atraparon la atención de la opinión pública durante este tiempo coincidió, además, con una serie de ficción de muy alto rating -Malparida- donde la abuela de la protagonista, un personaje traspasado por la venganza, era fiel devota de San La Muerte. Por otro lado, se han destinado segmentos de distintos ciclos de documentales (proyectados en canales como Infinito, NatGeo - "Tabú", etc.) para dar cuenta de las prácticas devocionales en torno al santo.

18 Esta dinámica se repite cada vez que hay un caso resonante en el cual se menciona al santo. Generalmente, al artículo de la noticia, se le adosa una breve descripción del culto. La información suele ser reiterada de modo viral.

Debates do NER, Porto Alegre, Ano I5, N. 25, P. I7I-I96, JAN./Jun. 2014 
carcelarios había sido registrada por los medios en el pasado, pero a partir de este caso se vuelven muy profusas las menciones del santo vinculadas a lo delictivo. Empiezan a abundar calificaciones tales como "el santo de los delincuentes" (27 veces) y variantes similares, que se vuelven el calificativo más usado, por sobre "santo popular" (3 veces) y aun sobre "santo pagano" (19 veces). De este modo, la criminalización se impone a una impugnación católico-céntrica de la devoción ("santo pagano"), aunque en varios artículos ambas perspectivas se refuerzan. Indagando en el tipo de noticia en donde tiene lugar la referencia al santo, encontramos que las 18 menciones realizadas durante 2008-2009 se distribuyen indistintamente entre diversas secciones de los medios estudiados. Sin embargo, de las 79 menciones del bienio 2010-2011, el 76,7\% corresponden únicamente a la sección Policiales. Esta asociación generaliza la adopción de esta imagen por individuos en conflicto con la ley e invisibiliza el hecho de que muchos policías también son devotos del mismo, solicitando su protección frente a la posibilidad de la muerte que potencialmente enfrentan en el ejercicio de su profesión. Particularmente después del caso Marcelito, la presencia de San La Muerte (imagen, tatuaje, estampa, calcomanía, etc.) que tenga un sospechoso o se halle en la escena de un crimen se torna - en el discurso periodístico - en marca que refuerza el carácter criminal de la persona imputada, dándose una trasposición de lo penal a lo religioso. La estigmatización criminalizante produce un efecto de refuerzo a la impugnación católico-céntrica, de tal modo que un crimen en el que esté implicado un creyente de una religión distinta de las mayoritarias pareciera una propiedad de la religión de dicho sujeto. En el caso opuesto, si el delito es cometido por un creyente católico, por ejemplo, lo que es puesto en cuestión es la responsabilidad de dicho individuo, sin mencionarse de a qué religión pertenece.

\section{MICRO-REGULACIONES SOCIALES}

Existen otras regulaciones sociales que aumentan el costo social de profesar esta devoción. El impacto de estas acciones cotidianas, que pretenden

Debates do NER, Porto Alegre, Ano I5, N. 25, P. I7I-I96, JAN./Jun. 2014 
controlar o eliminar las prácticas y representaciones de este culto, no alcanza la difusión masiva de la estigmatización construida por los medios de comunicación, pero se refuerza con la misma. Estas micro-regulaciones también se retroalimentan con el patrón valorativo católico y se manifiestan en repudios - generalmente espontáneos - de múltiples individuos al entrar en contacto con diversas manifestaciones públicas de este culto.

A modo de ejemplo podemos destacar la escasa presencia de imágenes y ermitas del santo en el espacio urbano - en el ámbito suburbano o, más aún, en el espacio rural suelen tener una existencia más duradera. Sus estatuillas y altares son destruidos de modo corriente por vecinos y activistas religiosos, sea por una motivación de explícita impugnación religiosa sea por el deseo de no convivir con una imagen de connotaciones esotéricas o delictivas ${ }^{19}$. Aquí también se pueden incluir los repudios que sufren algunos santuarios en las manifestaciones públicas de fe durante las celebraciones del santo. Estos se producen según los vínculos que establece cada centro de culto con el barrio, su interacción con los vecinos, su visibilidad y apertura a la calle ${ }^{20}$, etc.

Otra modalidad registrada podría denominarse 'acoso virtual' (cibertrolling) y consiste en la intervención de católicos, evangélicos y ateos, en sitios y foros web dedicados al santo. Estos espacios virtuales destinados a la transmisión de conocimientos sobre esta devoción y a la socialización de pedidos y testimonios entre fieles, se ven alterados regularmente por comentarios descalificadores vertidos por practicantes de las religiones más difundidas. El principal modo de ataque es la satanización de esta

19 Tenemos experiencia directa de la destrucción reiterada de una ermita en el barrio porteño de Chacarita. Nos han referido de otras situaciones similares en Quilmes y Lomas de Zamora. Por los medios, sabemos de un suceso equivalente en Catamarca y Mendoza. Un devoto denuncia otra destrucción en La Calera, Córdoba, en un sitio web dedicado a este culto.

20 Participamos de la primera peregrinación realizada por el santuario 'Santuario Jardín de San La Muerte', en Victoria. Jóvenes del barrio censuraron dicha expresión de fe con gritos en favor de Cristo y de la Virgen. Además, ligaron a esta devoción con 'la macumba'

Debates do NER, Porto Alegre, ANo I5, N. 25, P. I7I-I96, JAN./Jun. 20 I4 
creencia, sobre todo por ciertos grupos evangélicos (Wynarczyk, 2007). Estas intervenciones obligan a la acción permanente de los moderadores de foros en pos de mantener un clima propicio para los devotos y restablecer la legitimidad del culto.

\section{LOS CUIDADORES DE SANTUARIOS Y SUS ESTRATEGIAS DE LEGITIMACIÓN}

Como ya se ha dicho, la presencia pública del culto a San la Muerte se ha incrementado en un contexto que favorece su visibilidad y crecimiento. Desde su asentamiento en el conurbano bonaerense, la devoción encuentra aquí una de sus áreas de mayor desarrollo: prácticamente la mitad de los santuarios que hemos relevado se ubican en esta zona. Hay una amplia diversidad de apropiaciones del culto, en donde difieren las creencias y prácticas de los devotos de los lugares de origen, entre los migrantes y sus descendientes, y de aquellos que acceden posteriormente al culto. Esta variedad en las formas de vivir la devoción al Santo, se asienta en la autonomía y vínculo personal que sostienen cotidianamente los fieles con los santos populares. Más allá de esto, existen ciertas convenciones así como una dinámica producción de discursos y prácticas de fe que, aunque no estén formalmente establecidas, circulan entre la gran cantidad de devotos. Como mencionamos anteriormente, tanto los santuarios y las redes sociales en Internet que habilitan la socialización de experiencias y prácticas religiosas; como también los medios de comunicación, los libros de devoción comercializados en Santerías, construyen y transmiten religión extra-institucionalmente. Estas redes brindan contención, guía e instrucción a los devotos sobre cómo vincularse con la divinidad para acceder a su protección y favores. Estos medios que difunden religiosidad son importantes al tratarse de un culto popular no organizado jerárquicamente y sin una doctrina centralizada (Carozzi, 2006). Los santuarios dedicados al santo se conforman como lugares que nuclean cierto 'saber religioso' desarrollando sus actividades autónomamente. Según la accesibilidad a los mismos podemos categorizarlos como santuarios privados, semi-públicos y públicos (de acuerdo a indicadores tales como las restricciones físicas de acceso y el

Debates do NER, Porto Alegre, Ano I5, N. 25, P. I7I-I96, JAN./Jun. 2014 
control sobre lo que acontece en estos espacios). Estos centros devocionales no suelen sostener vínculos de comunicación y/o intercambio entre ellos, y en ocasiones emergen conflictos al disputar su legitimidad. Cada santuario propone su propia forma de sanación espiritual habilitando una variedad de propuestas religiosas, que algunos autores identifican como característico de la plasticidad de las manifestaciones populares, siendo adaptativas y permitiendo el cambio y la diversidad (González Martínez, en Calzato. 2009 , p. 16). Aquellos devotos que instalan y/o se hacen cargo del cuidado de altares y santuarios, se constituyen -la mayoría de las veces- en agentes religiosos intermediarios, santificadores, multiplicadores del culto (Frigerio; Rivero, 2003). Estas personas se presentan como mediadores privilegiados con el santo (ofreciendo trabajos de sanación espiritual, videncia, limpiezas, bendiciones, etc.) y sus principales intérpretes, teniendo un rol activo y performativo en los diversos rituales (de iniciación en el culto, celebración, sanación, etc.), gestionando prácticas devocionales y actividades dentro del santuario.

Frente a las distintas regulaciones externas estatales y sociales sobre esta devoción, los cuidadores de santuarios se constituyen como agentes activos en la interacción con el espacio público y despliegan acciones en pos de desestigmatizar y normalizar la práctica devocional (Frigerio; Wynarczyk, 2008). Al establecerse como representantes legítimos del culto, son convocados por los medios de comunicación como interlocutores válidos sobre las prácticas devocionales con San La Muerte. A diferencia de otros grupos religiosos periféricos (Frigerio; Wynarczyk, 2008) estos actores religiosos no han llevado adelante acciones planificadas con motivo de mejorar su imagen en los medios de comunicación. Por el contrario, adoptan estrategias defensivas: ante una convocatoria externa, se muestran selectivos frente a quien sea el interlocutor, accediendo o no al diálogo. En relación a esto, algunos santuarios han mostrado conocimiento y alertas ante determinados programas y sus intenciones en el tratamiento de esta devoción. A modo de ejemplo, en la página web del Santuario ubicado en el barrio porteño de Once $^{21}$, sus cuidadores realizan una convocatoria de prensa dando cuenta de

${ }^{21}$ Disponible en: http://cultosanlamuerte.com.ar . Acesso en: dic. 2013.

Debates do NER, Porto Alegre, Ano I5, N. 25, P. I7I-I96, JAN./Jun. 20 I4 
su desconfianza frente a los medios de comunicación, accediendo a hablar solo a la prensa que ellos consideren 'seria' y bienintencionada con el culto.

Frente a las descalificaciones hacia el Santo desde una perspectiva demonizante o criminalizadora, observamos un fuerte hincapié por parte de los referentes de santuarios en explicitar que ellos sólo trabajan para el 'bien y la luz'. Más aún, como portavoces del Santo, sostienen que él quiere ser invocado para fines benéficos y marcan su cercanía con Dios, a pesar de que reconocen que son posibles otras invocaciones (que deben conocerse para poder contrarrestar su efecto), que algunos utilizan, respetan y otros repudian. Estos mediadores construyen una narrativa integrando símbolos que refieren al bien (la luz, la pureza) y a la estética propia del santo (muerte, esquelética, negra). En esta construcción, tienden a diluirse aquellos rasgos que en la devoción podrían ser catalogados de negativos para atraer nuevos fieles - particularmente la posibilidad de invocar al santo 'para causar daño' - atribuyendo estos rasgos a la falta de información sobre la devoción o a la acción de otros mediadores que lucran invocando a esta entidad (Frigerio; Rivero, 2003). En la construcción de creencias y prácticas, los encargados incorporan elementos católicos y de otras tradiciones - Umbanda, New Age, chamanismo, espiritismo - según sus propias trayectorias espirituales y biográficas. La presencia de lo católico se evidencia además en oraciones (padrenuestros, avemarías y rosarios) y otros ritos como por ejemplo las bendiciones y el uso de agua bendita. Varios cuidadores además se reconocen como católicos, diferenciándose, negando o mostrándose indiferentes frente a la Iglesia institucional que proscribe estas creencias populares. Inclusive, en el Santuario "Honor a mi señor", ubicado en Wilde, los encargados 'iniciados' en el culto ofrecen sacramentos como los católicos (bautismos, casamientos) pero por intermedio del santo, marcando un rito de pasaje en la devoción, una pertenencia y una protección divina.

Otro modo de lograr legitimidad es resaltar su origen local tanto en la presentación de la devoción como por la incorporación de diversos elementos tradicionales de la cultura del litoral, tales como el chamamé. Incluso, algunos referentes de santuarios argumentan ser correntinos o tener alguna ascendencia de este tipo, inscribiéndose en esta tradición cultural que les

Debates do NER, Porto Alegre, Ano I5, N. 25, P. I7i-I96, JAn./Jun. 20 I4 
otorgaría mayor autoridad en el tema, aunque esta apelación al litoral no suele ser verdadera en muchos casos.

Los cuidadores de santuarios dan cuenta de la pertenencia social diversa de los devotos de San la Muerte, los cuales no solo provienen de sectores populares sino también de estratos medios y altos. Esta aclaración pretende desvincular el culto de sujetos en conflicto con la ley, buscando generar 'prestigio' al destacar la presencia de devotos que provienen de la esfera policial, judicial, política y de profesiones liberales.

Buscando mejorar la presencia pública del culto, algunos santuarios despliegan otras estrategias de legitimación y socialización con el barrio brindando servicios sociales como 'merenderos', 'apoyo escolar' o realizando eventos de interés público sin finalidad religiosa explícita, que convocan a los vecinos más allá de las actividades y prácticas devocionales que allí tienen lugar. Como ejemplo podríamos citar el santuario de Wilde en donde se desarrolla un espacio de apoyo escolar y merendero para los niños del barrio. Otro centro de devoción ubicado en Misiones, 'Capilla y Campo San la Muerte', se caracteriza por sus actividades solidarias, que son registradas por la prensa local. Pelusa, la encargada del templo y un grupo de colaboradores nucleados en una organización llamada: 'Corazones solidarios', desarrollan diversos emprendimientos sociales dirigidos a niños y a aquellos más necesitados de la zona. No solo brindan una ayuda espiritual sino que procuran un socorro material a quienes lo necesiten, respaldados en la figura del santo.

Una última estrategia de legitimación es procurar un reconocimiento más global por parte de la sociedad buscando distintos tipos de reconocimiento oficial, mostrando la gran cantidad de santuarios en Argentina y aún en otros países e invocando la reciente producción académica sobre la devoción así como los artículos periodísticos sobre el santo (Frigerio; Rivero, 2003). Respecto del aval oficial, ya hemos mencionado la negativa del Registro de Cultos a inscribir organizaciones religiosas ligadas a esta devoción. Esta instancia, pese a ser la principal, no agota otras variantes en las que se busca algún tipo de reconocimiento. Así, el santuario de Wilde, promociona públicamente (en la fachada de su edificio, en su página de

Debates do NER, Porto Alegre, Ano I5, N. 25, P. I7I-I96, JAN./Jun. 20 I4 
Facebook ${ }^{22}$ ) su inscripción ante la Dirección Nacional del Derecho de Autor y el número de expediente del trámite ante el Registro de Cultos, que a pesar de no haber sido aprobado se hace uso de esa referencia. Por otro lado, a nivel municipal, el santuario solicita permisos para realizar los festejos al Santo, hecho que luego intenta ser capitalizado por los cuidadores como un reconocimiento tácito. Con estos avales de organismos públicos, intentan demostrar vinculaciones con la esfera pública y acrecentar su legitimidad.

En el ámbito cultural, podemos citar el caso de Aquiles Coppini, reconocido por la Cámara de diputados de la Nación por su labor artística, quien apela a este homenaje de carácter 'oficial/cultural' como credencial habilitante para legitimarse en diversos ámbitos presentándose como una figura pública - en cuanto artesano/artista - que se complementa con su rol de agente religioso y tallador de San la Muerte auto-legitimado por su recorrido biográfico, por haber estado preso con condena perpetua en una cárcel de Corrientes.

\section{CONCLUSIONES}

En este trabajo nos propusimos indagar sobre las diversas regulaciones estatales y sociales que repercuten en la devoción al santo popular San la Muerte, en la Argentina. Por un lado, fuimos describiendo las diversas legislaciones sobre lo religioso, junto con el funcionamiento del Registro Nacional de Cultos (los requerimientos que supone y los beneficios que implica). Frente a las dificultades que suscita el reconocimiento oficial del culto a San la Muerte, se adjudican problemas en el cumplimiento de las formalidades necesarias para la inscripción, que dejarían en evidencia la dificultad de grupos religiosos de estratos menos calificados para poder satisfacer las exigencias del trámite. Sin embargo, nos resulta relevante destacar las resistencias sociales y conflictos de intereses que se juegan en su inscripción.

${ }^{22}$ Disponible en: https://www.facebook.com/pages/Santuario-honor-a-mi-se\%C3\%B1orwilde/333526243408291. Acesso en: dic. 2013.

Debates do NER, Porto Alegre, Ano I5, N. 25, P. I7I-I96, JAN./Jun. 2014 
$\mathrm{Al}$ abordar los controles sociales que aumentan el costo social de profesar la devoción a este santo detectamos dos grandes vertientes. La primera y principal se relaciona con la influencia del catolicismo en cuanto garante de la legitimidad social de la creencia, impregnando su valoración de los fenómenos religioso. En segundo término, identificamos la estigmatización de este culto por la generalización de su adopción (sea por un deseo religioso de protección o como signo de transgresión) por parte de individuos de sectores empobrecidos en conflicto con la ley. Estas dos impugnaciones las encontramos en los medios de comunicación masiva, reforzándose mutuamente. Particularmente a partir de 2010, con la acumulación de hechos delictivos de gran difusión en la prensa, la impugnación prevaleciente es la delictiva. Encontramos otras micro-regulaciones, las cuales se manifiestan en la acción cotidiana - y generalmente espontánea - de múltiples individuos al entrar en contacto con diversas manifestaciones públicas de este culto.

Por último nos abocamos a las dinámicas desarrolladas en algunos santuarios a San la Muerte, indagando cómo se van constituyendo en centros autónomos de difusión religiosa y sus encargados en agentes religiosos, interlocutores legítimos y mediadores con lo sagrado. Estos referentes despliegan una serie de estrategias para legitimar el culto ( $\mathrm{y}$ a su vez, legitimarse a ellos mismos en su rol). Entre ellas podemos destacar: la vinculación selectiva con los medios de comunicación, la construcción de cuerpo doctrinario rescatando los aspectos más positivos del santo, la fusión con prácticas e imágenes católicas, su inscripción en tradición cultural litoraleña, la pertenencia de fieles a diversos sectores sociales, servicios sociales al barrio y búsqueda de reconocimientos por entes públicos.

Pese a las regulaciones, esta devoción no deja de incrementar su presencia. Se caracteriza por un dinamismo y diversidad en las apropiaciones que realizan los devotos y 'especialistas', fusionándose con otras tradiciones religiosas y culturales. 


\section{REFERENCIAS}

BAHAMONDES GONZALEZ, Luis. San La Muerte una propuesta alternativa en la sociedad de hoy. Religión y Cultura, n. XIII, p. 173-181, 2007. BECKFORD, James. Social Theory and Religion. Cambridge: Cambridge University Press, 2003.

BIANCHI, Susana. Historia de las religiones en Argentina. Las minorías religiosas. Buenos Aires: Sudamericana, 2003.

CALZATO, Walter. Narrativa, identidad y sanación en las dueñas del santo. San La Muerte, Buenos Aires, Argentina. In: Congreso Internacional de Americanistas, 53, Julio 2009. México D.F, 2009.

CARASSAI, Sebastián. San la Muerte, el "santo non santo": pertenecer tiene sus privilegios. In: DRI R. Simbolos y fetiches religiosos en la construcción de la identidad popular. Buenos Aires: Biblos, 2012.

CAROZZI, María Julia; MIGUEZ, Daniel. Múltiples versiones del más justo de los santos. In: Vv.Aa. San la Muerte: una voz extraña. Buenos Aires: Editorial Arte Argentina, 2005.

CATOGGIO, Soledad. Gestión y regulación de la diversidad religiosa en la Argentina. Políticas de "reconocimiento" estatal: el Registro Nacional de Cultos. In: MALLIMACI, Fortunato. Religión y politica: perspectivas desde América Latina y Europa. Buenos Aires: Biblos, 2008.

CERRUTTI, Raúl. San La Muerte, Selecciones folklóricas, A. 1, n. 5, 1965.

FRIGERIO, Alejandro. Repensando el monopolio religioso del catolicismo en la Argentina. In: CAROZZI, María Julia; CERIANI, César. Ciencias sociales y religión en América Latina: Perspectivas en debate. Buenos Aires: Biblos/ACSRM, 2007.

O paradigma da escolha racional: mercado regulado e pluralismo religioso. Tempo Social, n. 20. v.2, p. 17-39, 2008.

Debates do NER, Porto Alegre, Ano I5, N. 25, P. I7i-I96, JAn./Jun. 20 I4 
Questioning religious monopolies and free markets: The role of the State, the church (es) and secular agents in the management of religion in Argentina. Citizenship Studies, v. 16, p. 997-1011, 2012.

FRIGERIO, Alejandro; RIVERO, Carlos. San La Muerte en la metrópolis: Procesos de eclesificación de cultos populares. In: 51 ICA - Congreso Internacional de Americanistas, Chile. 2003.

FRIGERIO Alejandro; WYNARCZYK Hilario. Cult controversies and government control of New Religious Movements in Argentina (19852001). In: RICHARDSON J. (Ed.) Regulating Religion: Case Studies from Around the Globe. New York: Kluwer Publishers, 2004. p. 453-475.

. Diversidad no es lo mismo que pluralismo: Cambios en el campo religioso argentino y lucha de los evangélicos por sus derechos religiosos (1985-2000). Sociedade e Estado n. 23. v.2. p. 227-260, 2008.

GENTILE, Margarita. Escritura, oralidad y gráfica del itinerario de un santo popular sudamericano: San La Muerte (siglos XX y XXI). Espéculo: Revista de Estudios Literarios, n. 37, 2007.

GIMENEZ BELIVEAU, Verónica; ESQUIVEL, Juan Cruz. Las creencias en los barrios o un rastreo de las identidades religiosas en los sectores populares urbanos del Gran Buenos Aires, Sociedady Religión, n. 14/15, p. 17-128, 1996.

GRACIANO, Frank. Cultures of devotion: folk saints of Spanish America. Oxford: Oxford University Press, 2007.

GRIM, Brian; FINKE, Roger. International Religion Indexes: Government Regulation, Government Favoritism, and Social Regulation of Religion. Interdisciplinary Journal of Research on Religion, v. 2, 2006.

. Religious Persecution in Cross-National Context: Clashing Civilizations or Regulated Religious Economies? American Sociological Review, v. 72. n. 4, p. 633-658, 2007. 
LÓPEZ FIDANZA, Juan Martín; GALERA, María Cecilia. Religiosidad popular en el siglo XXI: Transformaciones de la devoción a San la Muerte en Buenos Aires. Estudios Cotidianos n.1. v.1. p. 84-99, 2012.

MALLIMACI, Fortunato. Prólogo. In: ESQUIVEL; GARCIA; HADIDA; HOUDIN (Comps.) Creencias y religiones en el Gran Buenos Aires: El caso de Quilmes. Buenos Aires: Universidad Nacional de Quilmes, 2001.

MALLIMACI, Fortunato; GIMENEZ BELIVEAU, Verónica Creencias e increencia en el Cono Sur de América. Entre la religiosidad difusa, la pluralización del campo religioso y las relaciones con lo público y lo político. Revista Argentina de Sociología, A. 5. n. 9, 2007.

MALLIMACI, Fortunato. Atlas de las creencias religiosas en la Argentina. Buenos Aires: Biblos, 2013.

MÍGUEZ, Daniel; GONZALES, Angeles. Las creencias de los Pibes Chorros: dimensiones contestatarias de una religión minimalista. Ponencia presentada en las II Jornadas de Ciencias Sociales y Religión, Buenos Aires. 2002.

MÍGUEZ, Daniel. Inscripta en la Piel y en el Alma: Cuerpo e Identidad en Profesionales, Pentecostales y Jóvenes Delincuentes. Religiao e Sociedade, n. 22. v.1. p. 21-57, 2002.

. Canonizaciones y Moralidades en Contextos de Pobreza Urbana. Las Lógicas del Orden y la Transgresión en la Argentina de Fines del Siglo XX. Cultura y Religión VI, v.1, p. 241-274, 2012.

NOYA, Emilio. San La Muerte. El Litoral. 1968.

RICHARDSON, James. The Sociology of Religious Freedom: A Structural and Socio-Legal Analysis. Sociology of Religion, n.7. v.3. p. 271-294, 2006.

STARK, Rodney; FINKE, Roger. Acts of faith: explaining the human side of religion. Berkeley: University of California Press, 2000.

WYNARCZYK, Hilario. Ciudadanos de dos mundos. La entrada de los evangélicos conservadores a la vida pública desde los 80 en la Argentina. Tesis (Doctorado). Universidad Católica Argentina, 2007.

Debates do NER, Porto Alegre, Ano I5, N. 25, P. I7i-I96, JAn./Jun. 20 I4 
YANG, Fenggang. The Red, Black, and Gray Markets of Religion in China. Sociological Quarterly, n. 47. p. 93-122, 2006.

. Oligopoly Dynamics: Consequences of Religious Regulation, Social

Compass. n. 57. v.2. p. 194-205, 2010.

Recebido em: 18/07/2013

Aprovado em: 30/12/2013 